13 - ORIGINAL ARTICLE

TECHNICAL SKILL

\title{
Comparison between the traditional and the new training model using rabbits in the assessment $^{1}$
}

\author{
Comparação entre o tradicional e o novo modelo de treinamento utilizando coelhos para a \\ avaliação
}

\begin{abstract}
Victor Araujo Felzemburgh ${ }^{\mathrm{I}}$, Haroldo Araújo Sampaio" ${ }^{\mathrm{II}}$, Gilberto Ferreira de Abreu Junior ${ }^{\mathrm{III}}$, José Humberto Oliveira Campos ${ }^{\mathrm{IV}}$
IMD, Volunteer Faculty, Division of Surgical Technique and Experimental Surgery I, EBMSP, Salvador-BA, Brazil. Main author. Responsable for conception, design, intellectual and scientific content of the study.

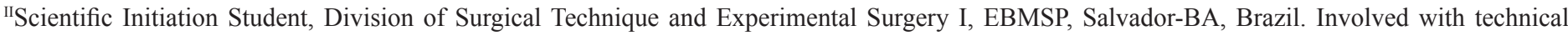
procedures and acquisition of data.

IIIMD, Associate Professor, Division of Surgical Technique and Experimental Surgery I, EBMSP, Salvador-BA, Brazil. Analysis, interpretation of data and critical revision.

${ }^{\text {IV }} \mathrm{PhD}$, Full Professor, Division of Surgical Technique and Experimental Surgery I, EBMSP, Salvador-BA, Brazil. Conception, design of the study and critical revision.
\end{abstract}

\begin{abstract}
PURPOSE: Compare the new training model for vessel ligation with the traditional using rabbits in the assessment.

METHODS: From 106 academics of the Division of Operative Technique and Experimental Surgery, 36 were divided into two groups and offered them two training models of ligature. The group was invited to participate to an experimental procedure with rabbits and reproduce the technique trained. The procedure consisted of performing ligatures in saphenous veins of the legs of rabbits. The students were evaluated by objective criteria by an observer evaluator and answered a questionnaire at the end of the procedure.

RESULTS: The medical students who have had training with the new model had a higher number of hits compared to the other group performing ligatures without clamping with hemostatic forceps $(\mathrm{p}<0.05)$. There was also a higher number of hits for the new model group to perform ligation temporary and permanent ligation with the use of forceps $(\mathrm{p}>0.05)$. The questionnaires indicated that the new model develops more ability to work in groups ( $\mathrm{p}=0.088$ ).
\end{abstract}

CONCLUSIONS: The project promotes the implementation of the new model for training ligature, indicating that the new model is better to the traditional surgical practice.

Key words: Saphenous Vein. Ligation. Hemostasis. Rabbits.

\section{RESUMO}

OBJETIVO: Comparar o novo modelo de treinamento de ligadura de vaso com o tradicional a partir de modelo experimental com coelhos.

MÉTODOS: De 106 acadêmicos da Disciplina de Técnica Operatória e Cirurgia Experimental, 36 foram distribuídos em dois grupos e foram ofertados a eles dois modelos de treinamento de ligadura. O grupo foi convidado a participar de procedimento experimental com coelhos para a reprodução da técnica treinada. O procedimento consistiu da realização de ligaduras nas veias safenas das coxas dos coelhos. Os acadêmicos foram avaliados por critérios objetivos por avaliador observador e responderam a um questionário ao final procedimento.

RESULTADOS: Os acadêmicos que tiveram treinamento com o novo modelo tiveram maior número de acertos quando comparado o outro grupo para realização de ligaduras sem clampeamento com pinças hemostáticas $(\mathrm{p}<0,05)$. Houve maior número de acertos para realização de ligadura temporária e de ligadura definitiva com uso de pinças $(\mathrm{p}>0,05)$ para o grupo do novo modelo. Os questionários indicaram que o novo modelo desenvolve mais a habilidade de trabalho em grupo $(\mathrm{p}=0,088)$.

CONCLUSÃO: O projeto favorece a implantação do novo modelo para treinamento de ligaduras, indicando que o novo modelo se aproxima mais com a prática cirúrgica que o tradicional.

Descritores: Veia Safena. Ligadura. Hemostasia. Coelhos. 


\section{Introduction}

The basic principles of surgery, as the acts of cut, suture and ligature, belong to the medical and surgical resident formation ${ }^{1}$. Proper training allows rapid, skill development and perfection of technique $^{2}$. Even with the advent of new and modern surgical techniques, the fundamental principles of dieresis, hemostasis and synthesis remain unchanged and must be taught ${ }^{1}$.

Hemostasis is one of the fundamental principles of the surgery, which aims to prevent or halt the onset of bleeding ${ }^{3}$. Among the techniques of hemostasis, there are temporary methods and definitive ${ }^{4}$. The maneuver is intended to prevent blood loss that can compromises the blood volume of the patient, keeping clean the operative field and preventing the formation of collections of blood and clots that can favor infections ${ }^{3}$.

The intense pressure and the need for knowledge of students in various areas stimulate the teacher to program different techniques of training 5 . The training through simulations and experimental models, in educational institutions under the direct supervision of experienced and qualified tutors allows the students to learn more effectively and a non-iatrogenic way ${ }^{2}$.

\section{Methods}

The study protocol was analyzed and approved by the Ethic Commission on Animal Research of Bahiana School of Medicine and Public Health (EBMSP). The use of laboratory animals followed the ethical code for animal experimentation of the Council for International Organization of Medical Sciences. The procedures were also in accord with the Ethical Committee on Human Research of EBMSP.

From a total group of 106 students of operative technique and experimental surgery discipline from EBMSP, was offered to half the number of students classroom training techniques with the traditional model ligation (control group) and the other half with the new training model vessel ligation (experimental group). The two groups were not aware that the training models were different (Figure 1). Two groups of 18 students from each group were aleatory selected with attention to the following exclusion criteria: prior experience with experimental surgery on animals, fear or no fear that prevents contact of students with experimental surgery on animals.

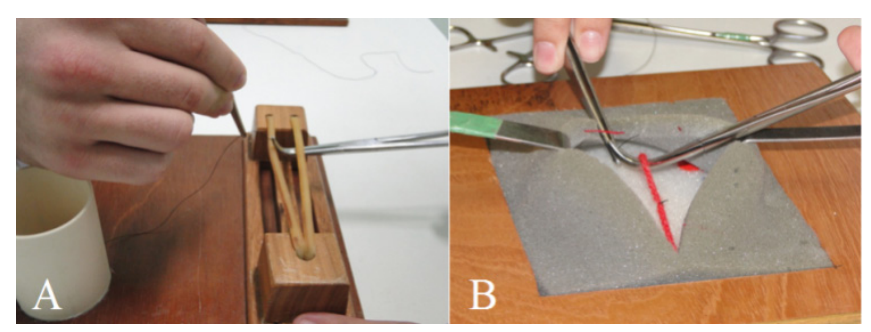

FIGURE 1 - Training vessel ligation. A. Traditional model. B. New training model.

The traditional model uses a rigid structure of wood and a latex semi-rigid wire for ligature technique training (Figure 2). The new model involves the use of flexible polyurethane structures positioned in planes that can be manipulated and incised into sets wool yarn and cotton simulating vessels of different calibers. Perpendicular to the first plane cotton yarn-caliber inside the polyurethane material simulates superficial capillaries. (Figure 3) At the lower range, in its larger diameter, two strands of wool, one red and the other blue simulates an artery and a vein, respectively. There is a broken strand of wool, representing a ruptured vessel, and a red spot remembering a hidden bleeding vessel (Figure 4).
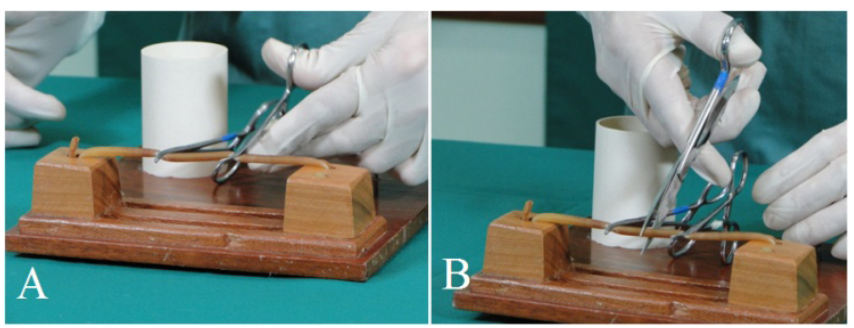

FIGURE 2 - Traditional training model. A. Clamping latex wire. B. The cut of the latex wire demonstrates the high cost of model.
A
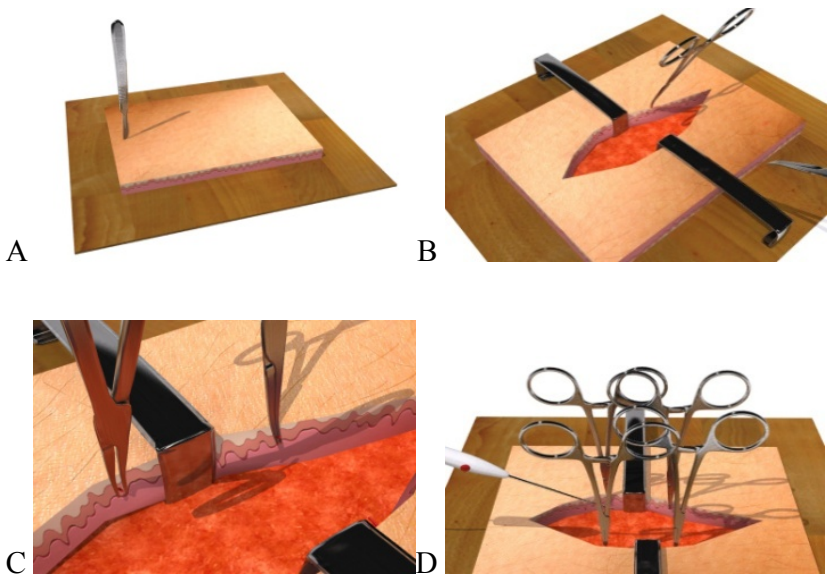

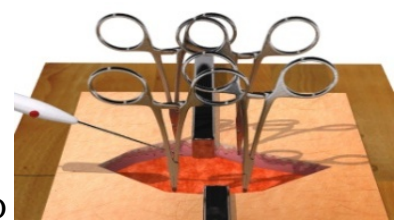

FIGURE 3 - Three-dimensional reproduction of the new training model. A. Simulation of incision. B. Manipulation of two separated plans. C. 3D reproduction of small-caliber vessels of cotton. D. Cauterization vessel simulation. 


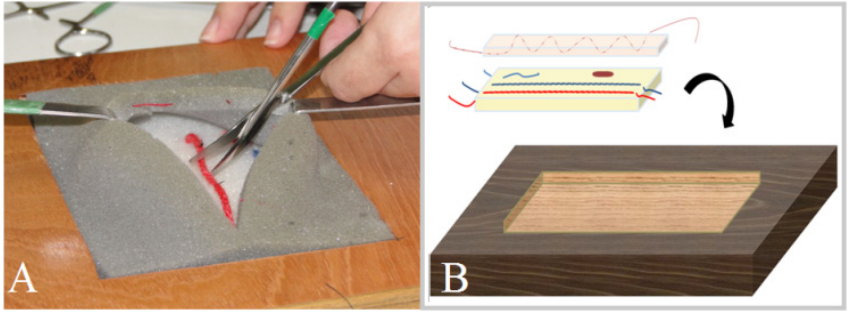

FIGURE 4 - New training model. A. Future replacement cost effectively. B. Model with flexible and separated plans.

In the experiment 18 rabbits were used (Oryctologus cuniculus), male, New Zealand race, aged 2 to 3 years, weighing 2.0 to $3.0 \mathrm{~kg}$, from the EBMSP. The animals were introduced to adapt to conditions 5 days before surgery with humidity of $50 \%$ average and medium temperature of $22^{\circ} \mathrm{C}$, using standard ration twice a day. The anesthetic protocol was adopted with ketamine $30 \mathrm{mg} / \mathrm{kg}$ and xylazine $5.0 \mathrm{mg} / \mathrm{kg}$ by intramuscular ${ }^{4,5}$.

\section{Procedure}

The animals were anesthetized and placed in dorsal decubitus on the operating table suitable for rabbits, the trichotomy and asepsis was made in the inner thighs of the animal. Each selected student had seen already the image of the anatomy of the thigh and the underlying vasculature before surgery. At first, the student performed the incision. The sub epithelial structures were separated and then the ligature was performed. The temporary ligature was executed at first and then two permanent ligation were made, with and without clamping with forceps. A cotton thread 4.0 was used in all ligatures. After the procedure, the skin was closed with simple stitches with nylon 5.0 (Figure 5). The entire procedure was supervised by a trained person.
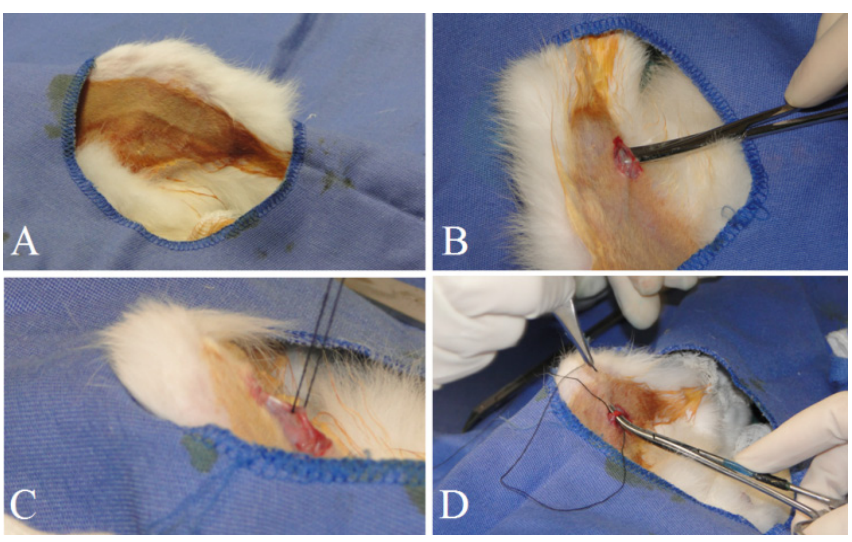

FIGURE 5 - Experimental surgery. A. Anatomic location of the saphenous vein. B. Exposure of the vein. C. Vein ligation without clamping. D. Temporary ligation of saphenous vein.

The 36 students were evaluated by objective criteria during a surgical procedure experimental rabbit. The evaluator observer was unaware of the difference between the groups. There was application of a questionnaire after surgery evaluating models of training and research project.

\section{Results}

Results concerning the vessel ligation without clamping (Table 1), temporary ligation (Table 2 ) and vessel ligation using clamping (Table 3) showed almost entirely a higher percentage of correct responses for the experimental group than control. The realization of correct presentation of the wire and technique performed correctly in performing vessel ligation without clamping showed statistics significant results.

TABLE 1 - Results concerning the correct answers of the vessel ligation without clamping.

\begin{tabular}{|ccccc}
\hline & $\begin{array}{c}\text { EG } \\
(\mathbf{\%})\end{array}$ & $\begin{array}{c}\text { CG } \\
(\mathbf{\%})\end{array}$ & $\begin{array}{c}\text { D } \\
(\%)\end{array}$ & $\mathbf{p}$ \\
\hline $\begin{array}{c}\text { Correct use of } \\
\text { instrumental }\end{array}$ & 100 & 66.7 & 33.3 & 0.007 \\
\hline $\begin{array}{c}\text { Correct presentation of } \\
\text { the wire }\end{array}$ & 94.4 & 44.4 & 50 & 0.001 \\
\hline $\begin{array}{c}\text { Technique performed } \\
\text { correctly }\end{array}$ & 72.2 & 33.3 & 38.9 & 0.019 \\
$\begin{array}{c}\text { Obeyed the direction } \\
\text { of flow }\end{array}$ & 61.1 & 44.4 & 16.7 & 0.317 \\
\hline $\begin{array}{c}\text { Perform the technique } \\
\text { at the right time }\end{array}$ & 88.2 & 44.4 & 43.8 & 0.006 \\
\hline
\end{tabular}

$\mathrm{EG}=$ Experimental group $\mathrm{CG}=$ Control Group $\mathrm{D}=$ Difference $\mathrm{P}=$ significance level (Chi-square test)

TABLE 2 - Results concerning the correct answers of temporary ligation.

\begin{tabular}{|ccccc}
\hline & $\begin{array}{c}\text { EG } \\
(\mathbf{\%})\end{array}$ & $\begin{array}{c}\text { CG } \\
(\mathbf{\%})\end{array}$ & $\begin{array}{c}\text { D } \\
(\%)\end{array}$ & $\mathbf{p}$ \\
\hline $\begin{array}{c}\text { Correct use of } \\
\text { instrumental }\end{array}$ & 88.9 & 66.7 & 22.2 & 0.109 \\
\hline $\begin{array}{c}\text { Correct presentation of } \\
\text { the wire }\end{array}$ & 83.3 & 55.6 & 27.7 & 0.070 \\
\hline $\begin{array}{c}\text { Technique performed } \\
\text { correctly }\end{array}$ & 77.8 & 55.6 & 22.2 & 0.157 \\
$\begin{array}{c}\text { Obeyed the direction } \\
\text { of flow }\end{array}$ & 66.7 & 44.4 & 22.3 & 0.180 \\
\hline $\begin{array}{c}\text { Perform the technique } \\
\text { at the right time }\end{array}$ & 88.9 & 72.2 & 16.7 & 0.206 \\
\hline
\end{tabular}

$\mathrm{EG}=$ Experimental group $\mathrm{CG}=$ Control Group $\mathrm{D}=$ Difference $\mathrm{P}=$ significance level (Chi-square test) 
TABLE 3 - Results concerning the correct answers of the vessel ligation using clamping.

\begin{tabular}{|ccccc}
\hline & $\begin{array}{c}\text { EG } \\
(\%)\end{array}$ & $\begin{array}{c}\text { CG } \\
(\%)\end{array}$ & $\begin{array}{c}\text { D } \\
(\mathbf{\%})\end{array}$ & p \\
\hline $\begin{array}{c}\text { Correct use of } \\
\text { instrumental }\end{array}$ & 83.3 & 61.1 & 22.2 & 0.137 \\
\hline $\begin{array}{c}\text { Correct presentation of } \\
\text { the wire }\end{array}$ & 44.4 & 33.3 & 11.1 & 0.494 \\
\hline $\begin{array}{c}\text { Technique performed } \\
\text { correctly }\end{array}$ & 55.6 & 38.9 & 16.7 & 0.317 \\
$\begin{array}{c}\text { Obeyed the direction } \\
\text { of flow }\end{array}$ & 61.1 & 50.0 & 11.1 & 0.502 \\
\hline $\begin{array}{c}\text { Perform the technique } \\
\text { at the right time }\end{array}$ & 55.6 & 61.1 & -5.5 & 0.735 \\
\hline
\end{tabular}

$\mathrm{EG}=$ Experimental group $\mathrm{CG}=$ Control Group $\mathrm{D}=$ Difference $\mathrm{P}=$ significance level (Chi-square test)

During the evaluation of the survey, $27.7 \%$ more academics of the experiment group totally agreed that the new model trains the ability to group work $\mathrm{p}=0.088$, Chi-square test (Table 4). And 22.2\% more academics of the experimental group totally agreed that the model was suitable for training of the technique $\mathrm{p}=0.189$, Chi-square test (Table 5).

TABLE 4 - Ability to work in groups.

\section{EG (\%) CG (\%) D (\%)}

\begin{tabular}{cccc}
\hline Totally disagree & - & - & - \\
\hline Partially disagree & - & 16.7 & -16.7 \\
\hline Partially agree & 5.6 & 16.7 & 11.1 \\
\hline Totally agree & 94.4 & 66.7 & 27.7 \\
Total & 100 & 100 & - \\
\hline
\end{tabular}

$\mathrm{EG}=$ Experimental group $\mathrm{CG}=$ Control Group $\mathrm{D}=$ Difference
TABLE 5 - Suitable model for practical procedure.

$$
\text { EG (\%) CG (\%) D (\%) }
$$

\begin{tabular}{cccc}
\hline Totally disagree & - & - & - \\
\hline Partially disagree & - & 5.6 & -5.6 \\
\hline Partially agree & 5.6 & 22.2 & -16.6 \\
\hline Totally agree & 94.4 & 72.2 & 22.2 \\
Total & 100 & 100 & - \\
\hline
\end{tabular}

$E G=$ Experimental group $C G=$ Control Group $D=$ Difference

During the survey $100 \%$ of the students said they were pleased to participate in the research project.

\section{Discussion}

It is noted the difficulty of medical students related to vessel ligation and the correct handling of basic surgical instruments. The evolution of surgical techniques requires the development of new animal models for experimental surgery ${ }^{6}$.

Rats and mice are an option for animal models, but the literature does not show these animals as the best option for studies with similar characteristics to ours. These kind of animals are small, with the small saphenous vein, difficult to dissect and manipulate $i^{7}$. The model developed successfully proposed a model for training ligatures, especially for an audience of less experience (medical students).

The use of a large vein of smaller animals might be appropriate to the aims of the study. However the choice of an inferior caval vein can totally affect morbidity and mortality the experiment because of that vein is fundamental to hemodynamics ${ }^{8,9}$. The ligation would potentially induce hypoxemia and quickly lead thrombosis ${ }^{8}$.

At the first postoperative day, all rabbits were located in good general condition without protective reflex of the limb, without amendment to walk, not fulfilling diagnostic criteria of pain studied. All animals underwent the procedure successfully, highlighting the reproducibility of the technique.

The use of other animal models like dogs and cats could interfere with the emotional attitude of invited academics as described by Calasans-Maia et al. ${ }^{5}$.

In the evaluation of false ligation, the experiment 
group presented better results in relation to the number of hits. It demonstrates the advantages of the new model that promotes greater interaction between the academic with the training model and allows greater surgical approximation of reality. The model consists of yarns of wool red and blue (representing arteries and veins), also enables greater sense of depth to the surgical plans, noting the difference between the vessels and the need for ligation obeying the direction of blood flow.

The experimental group had the highest number of hits reproducing the technique "definitive ligation without clamping of the vessel", statistically significant to the following parameters: correct use of instrumentals, presentation of the wire, technique performed, obeyed the direction of the flow and performs the technique in right time. The new model allowed for greater security in the performance of the technique, with better weather, more interaction with the colleague.

The saphenous vein was chosen for the experiment because it is a superficial vein, easily accessible, of adequate size and caliber, which facilitates ligation and handling by students, and ensures greater reproducibility because of the anatomy more exuberant than in other animal models ${ }^{10}$. The procedure is also less invasive, resulting in less morbidity to the animal.

In assessing of the definitive ligation with clamping, the experimental group shows better results. The new model refers to the surgical practice facilitating learning and improving technical skills for experimental surgery in rabbits.

The new model has an important advantage in carrying out the definitive ligation with and without clamping: to enable students to simulate the cutting of vessels as a similar form from the cut of wool yarn. In the traditional model, the vessels were simulated by latex elastic tubes that could not be cut or disable the model, making the method difficult to reproduce and expensive. The importance of a developing reproductive method with low cost is well described in a model of splenectomy in rats $^{6}$.

When answering the questionnaire the academic could respond about his experience on participate of the experimental study. It was observed that all students were pleased to be invited to the research activity in both groups. A larger number of scholars in the experimental group agreed that the training allowed the experience of working together and developing the ability to interact and work in synch with his colleague. This finding underscores the ease of handling the new model and the need to interact with another person to carry out the procedures to a deeper plan.

More students in the experimental group, compared to the control group, agreed that the training model used in class is suitable for training the technique. Although both scholars undergoing stress, not knowing that there were groups being compared, the students felt more able to perform the procedure.

An experimental model should have similar characteristics to the object being tested and being able to be completely handled without the limitations of the object. The animal when used as a model most suit the characteristics of these and being put on trail ${ }^{5}$.

At the beginning of learning new skills, anxiety and insecurity about their own ability to perform the procedures are very present ${ }^{11}$. However, when the manual skills are learned and the steps are due after effective training, there is the growth of confidence and desire to apply their new skills ${ }^{11}$. This finding is similar to the experience observed by the research group that evaluated an experimental model in rabbits.

However, there is a big difference between academic medicine and surgical technique resident ${ }^{11,12}$. Students were still in a phase of training, require hands-on practice with the direct guidance of teachers, aides and assistants during the technique ${ }^{12}$. Through experience with the research project, students in this overview are encouraged and challenged in an interactive and balanced, to use acquired knowledge and skills and to progress and play experimental surgical procedure ${ }^{12}$.

\section{Conclusions}

The project promotes the implementation of the new model for training ligature, indicating that the new model is closer than traditional to the surgical practice. The experimental model was adequate for training ligatures and fully accepted by the medical students involved in the project.

\section{References}

1. Baranauskas MB, Margarido CB, Panossian C, Silva ED, Campanella MA, Kimachi PP. Simulation of ultrasound-guided peripheral nerve block: learning curve of CET-SMA/HSL anesthesiology residents. Rev Bras Anestesiol. 2008;58(2):106-11.

2. Ebram Neto J, De Paula PR, Celano RMG, Hirose K, Cauduro AB, Speranzini MB. Modelo de dispositivo para treinamento e avaliação das habilidades em técnica operatória. Acta Cir Bras. 1998;13(1):5860 .

3. Imamura R, Sennes LU, Chung D, Bohadana S, Tsuji DH. Injeção de gordura na prega vocal: efeitos do local de injeção sobre a configuração glótica e a distribuição espacial da gordura injetada. Rev Bras Otorrinolaringol. 2003;69(4);445-50.

4. Nakao M, Inoue CM, Aydos RD, Silva IS, Goldenberg S. Efeitos da ressecção parcial da cartilagem do septo nasal no desenvolvimento dos ossos da face de coelhos em crescimento. Acta Cir Bras. 1999; 14(1). Disponível em www.scielo.br/acb

5. Calasans-Maia MD, Monteiro ML, Áscoli FO, Granjeiro JM. The rabbit as an animal model for experimental surgery. Acta Cir Bras. 
2009;24(4):325-8

6. Pineda FI, Millan A, Morcillo J, Agustin JC. Laparoscopy surgery in rat model. J Laparoendosc Adv Surg Tech. 2010;20(6):575-6.

7. $\mathrm{Pu}$ LQ, Gdowiski GR, Graham AM, Ricci MA, Brassard R, Sniderman AD, Symes JF. Enhanced revascularisation after angiogenic stimulation in a rabbit model of bilateral limb ischaemia. Eur J Vasc Endovasc Surg. 1995;9:189-96.

8. Zhou J, May L, Liao P, Gross PL, Weitz JI. Inferior vena cava ligation rapidly induces tissue factor expression and venous thrombosis in rats. Arterioscler Thromb Vasc Biol. 2009;29(6):863-9.

9. Schimidt LR, Cardoso EJ, Schmidt RR, Silva CAJ, d'Acampora AJ. Radiologic analyses of caudal vein in Winstar rats. Acta Cir Bras. 2004;19(5):517-22.

10. Kapickis M, Lahiri A, Lim AY. Different angiogenic behaviour of ligated saphenous and epigastric vascular bundles in avascular environment: an in-vivo experimental study. Hand Surg. 2010;15(1):17-25.

11. Franco D, Medeiros J, Grossi A, Franco T. Suturing techniques method using bovine tongue. Rev Col Bras Cir. 2008;35(6):442-4.

12. Purim KSM. Oficina de cirurgia cutânea. Rev Col Bras Cir. 2010;37(4):303-5.

\section{Correspondence:}

Victor Araujo Felzemburgh

Avenida Juracy Magalhães Junior, 670

41960060 Salvador - BA Brasil

Tel.: (55 71)3346-4570

victor@ccp.med.br

Received: January 26, 2012

Review: March 22, 2012

Accepted: April 24, 2012

Conflict of interest: none

Financial source: none

${ }^{1}$ Research performed at the Nucleus of Experimental Surgery, Bahiana School of Medicine and Public Health (EBMSP), Salvador-BA, Brazil. 